PALGRAVE STUDIES IN POLITICAL LEADERSHIP SERIES

\title{
Technocratic Ministers and Political Leadership in European Democracies
}

Edited by António Costa Pinto, Maurizio Cotta, Pedro Tavares de Almeida 


\title{
Palgrave Studies in Political Leadership
}

\author{
Series Editors \\ Ludger Helms \\ University of Innsbruck \\ Innsbruck, Austria \\ Gillian Peele \\ International Relations \\ University of Oxford \\ Oxford, UK \\ Bert A. Rockman \\ Purdue University \\ West Lafayette, Indiana, USA
}

EBSCO Publishing : eBook Collection (EBSCOhost) - printed on 5/11/2018 8:56 AM via ULISBOA

AN: 1594142 ; Pinto, Antonio Costa, Cotta, Maurizio, Almeida, Pedro Tavares de.; Technocratic Ministers and Political Leadership in European Democracies 
Palgrave Studies in Political Leadership seeks to gather some of the best work on political leadership broadly defined, stretching from classical areas such as executive, legislative and party leadership to understudied manifestations of political leadership beyond the state. Edited by an international board of distinguished leadership scholars from the United States, Europe and Asia, the series publishes cutting-edge Research that reaches out to a global readership.

More information about this series at http://www.springer.com/series/14602 


\section{António Costa Pinto - Maurizio Cotta Pedro Tavares de Almeida Editors}

\section{Technocratic Ministers}

and Political Leadership in European Democracies

\section{palgrave macmillan}

EBSCO Publishing : eBook Collection (EBSCOhost) - printed on 5/11/2018 8:56 AM via ULISBOA

AN: 1594142 ; Pinto, Antonio Costa, Cotta, Maurizio, Almeida, Pedro Tavares de.; Technocratic Ministers and Political Leadership in European Democracies 


\section{Editors}

\author{
António Costa Pinto \\ University of Lisbon \\ Lisbon, Portugal
}

Pedro Tavares de Almeida

NOVA University of Lisbon

Lisbon, Portugal

\author{
Maurizio Cotta \\ University of Siena \\ Siena, Italy
}

\section{Palgrave Studies in Political Leadership \\ ISBN 978-3-319-62312-2 ISBN 978-3-319-62313-9 (eBook) \\ DOI $10.1007 / 978-3-319-62313-9$}

Library of Congress Control Number: 2017954363

(C) The Editor(s) (if applicable) and The Author(s) 2018

This work is subject to copyright. All rights are solely and exclusively licensed by the Publisher, whether the whole or part of the material is concerned, specifically the rights of translation, reprinting, reuse of illustrations, recitation, broadcasting, reproduction on microfilms or in any other physical way, and transmission or information storage and retrieval, electronic adaptation, computer software, or by similar or dissimilar methodology now known or hereafter developed.

The use of general descriptive names, registered names, trademarks, service marks, etc. in this publication does not imply, even in the absence of a specific statement, that such names are exempt from the relevant protective laws and regulations and therefore free for general use. The publisher, the authors and the editors are safe to assume that the advice and information in this book are believed to be true and accurate at the date of publication. Neither the publisher nor the authors or the editors give a warranty, express or implied, with respect to the material contained herein or for any errors or omissions that may have been made. The publisher remains neutral with regard to jurisdictional claims in published maps and institutional affiliations.

Cover illustration: The Grayson / Stockimo / Alamy Stock Photo

Printed on acid-free paper

This Palgrave Macmillan imprint is published by Springer Nature The registered company is Springer International Publishing AG The registered company address is: Gewerbestrasse 11, 6330 Cham, Switzerland 


\section{ACKNOWLEDGEMENTS}

This book is the outcome of a comparative research project on Technocratic Ministers in European Democracies launched in 2012 with the financial support of the Portuguese Foundation for Science and Technology under grant number PTDC/CPJ-CPO/118086/2010. The theoretical framework and methodological guidelines, as well as the preliminary versions of the papers on the selected national case studies, were presented and discussed by the contributors to this volume in two major occasions. The kick-off meeting was a panel organised at the $22 \mathrm{nd}$ World Congress of the International Political Science Association that took place in Madrid in July 2012. The subsequent meeting was an intensive 2-day workshop held in March 2013 at the Faculty of Social Sciences and Humanities, NOVA University of Lisbon, in which we benefitted from detailed comments and stimulating criticisms and suggestions by Manuel Alcántara Sáez (University of Salamanca, Spain), Michael Edinger (Friedrich Schiller University, Jena, Germany) and Patrick Dumont (University of Luxembourg). We also convened panels at the 7 th General Conference of the European Consortium for Political Research (Bordeaux, September 2013) and at the 24th World Congress of the International Political Science Association (Poznan, July 2016), comparing changing patterns of elite recruitment and the role of technocratic ministers in Europe and Latin America. We wish to thank Ursula Hoffman-Lange (University of Bamberg, Germany), Alfredo Joignant (Diego Portales University, Chile), Maria Celina de Araújo (Pontifical Catholic University of Rio de Janeiro, Brazil), Manuela Ortega-Ruiz and Francisco Javier Luque Castillo (University of Granada, Spain), Pedro Silveira (NOVA University of 
Lisbon, Portugal) and Goffredo Adinolfi (University Institute of Lisbon, Portugal) for their valuable contributions to a more comprehensive approach of the subject.

We are personally indebted to many other colleagues we met in workshops and academic conferences with whom we discussed the comparative framework and previous versions of national papers. That is the case of Octávio Amorim-Neto (Getúlio Vargas Foundation-Rio de Janeiro, Brazil), José Alvaro Moisés (University of São Paulo, Brazil), Duncan McDonnell (Griffith University, Australia), Adriano Codato (Federal University of Paraná, Brazil), and Marcelo Camerlo (Institute of Social Sciences, University of Lisbon).

We should also like to thank Adam Standring, for the copy-editing of the manuscript, and Stewart Lloyd-Jones, for preparing the index. Last but not least, we thank the contributors to this volume, for their excellent work and patience with the editors' demands throughout a lengthy process of manuscript revisions. Finally, we express our gratitude to the editors of the "Palgrave Studies in Political Leadership" Series; to Ambra Finotello, commissioning editor of Politics at Palgrave Macmillan, for her encouragement and assistance; and to the anonymous reviewers who provided detailed and pointed criticisms that greatly helped to improve the final manuscript. 


\section{CONTENTS}

1 Beyond Party Government? Technocratic Trends in Society and in the Executive

António Costa Pinto, Maurizio Cotta, and Pedro

Tavares de Almeida

2 Non-partisan Ministers Under the French Fifth

Republic (1959-2014)

Marie-Hélène Bruère and Daniel Gaxie

3 No More Political Insiders? Ministerial Selection in Sweden During the Post-WWII Period

Hanna Bäck and Thomas Persson

4 Shades of Technocracy: The Variable Use of Non-partisan Ministers in Italy

Luca Verzichelli and Maurizio Cotta

5 The Primacy of Experts? Non-partisan Ministers in Portuguese Democracy

António Costa Pinto and Pedro Tavares de Almeida 
6 The Selection and Deselection of Technocratic Ministers in Democratic Spain

Juan Rodríguez Teruel and Miguel Jerez Mir

7 Recruitment and Careers of Ministers in Central Eastern Europe and Baltic Countries

Elena Semenova

8 Variations in the Expert Ministerial Framework in Hungary and Romania: Personal and Institutional Explanations

Gabriella Ilonszki and Laurentiu Stefan

9 Turkey's Ministerial Elites: The Growing Importance of Technical Expertise Sabri Sayarı and Hasret Dikici Bilgin

10 Technocratic Government Versus Party Government? Non-partisan Ministers and the Changing Parameters of Political Leadership in European Democracies Maurizio Cotta

Index 